\title{
A rapid method for estimating the median diameter of the stem profile of Norway spruce (Picea abies Karst) trees
}

\author{
Maria Magdalena Vasilescu, \\ Cornel Cristian Teresneu, \\ Florin Dinulica
}

\begin{abstract}
The median diameter of a longitudinal section of the stem may be used to determine the stem volume. However, to calculate stem volume, many measurements of diameter at different heights along the stem are required. Therefore, this approach is not generally applied because time-consuming and expensive. Here, we propose a novel, more rapid method to obtain median diameter using the area of the stem profile. A total of 218 height/diameter classes from more than $\mathbf{5 0 0 0}$ spruce trees (Picea abies Karst.) were used to compute the median diameter using the classical method. In parallel, a regression model to assess the median diameter was developed. The strongest predictor of the median diameter for the stem profile was the diameter at breast height $\left(R^{2}=0.9985\right)$. Statistical analysis revealed that the height of the median diameter on the stem profile was $0.3 \times H$ (tree height). The model was verified on standing and felled trees, revealing that differences between classical computations and the proposed model were less than $2 \%$ in most cases $(86.24 \%$ of trees). The median diameter of the stem profile provides valuable information on stand architecture that could help in advancing our understanding on the mechanical stability of Norway spruce trees (i.e., delineating breakage point), growth model predictions, and competition among trees.
\end{abstract}

Keywords: Forest Mensuration, Median Diameter, Stem, Structure, Tree Stability

Tomusiak \& Zarzynski 2007, Van Laar \& Akça 2007). Alternatively, stem diameter at the center of wind resistance may be used to compute volume. This diameter is located at the center of gravity of the tree crown. The relative height of this point above the ground was used by Jonson in 1928; however, this model was abandoned in favor of more efficient ways to estimate stem volume (Van Laar \& Akça 1997).

Nonetheless, some equations use sections other than the cross-sectional area at the midpoint, or the cross-sectional area at the lower and upper end of the bole (Forslund 1982, Wiant et al. 1991, Yavuz 1999, Coble \& Wiant 2000, Wiant et al. 2002, Coble \& Lee 2003, Ozcelik et al. 2006). Hossfeld outlines the importance of the cross-sectional area at one-third of the stem length/height (Giurgiu 1979, Leahu

Department of Forest Engineering, Forest Management Planning and Terrestrial Measurements, Faculty of Silviculture and Forest Engineering, Transilvania University of Brasov, Sirul Beethoven 1, 500123, Brasov (Romania)

@ Maria Magdalena Vasilescu (vasilescumm@unitbv.ro)

Received: Dec 12, 2015 - Accepted: Sep 07, 2016

Citation: Vasilescu MM, Teresneu CC, Dinulica F (2017). A rapid method for estimating the median diameter of the stem profile of Norway spruce (Picea abies Karst) trees. iForest 10: 328-333. - doi: 10.3832/ifor1945-009 [online 2017-02-11]

1994, Leahu 2007, Van Laar \& Akça 2007, West 2009, Ducey \& Williams 2011, Durkaya \& Durkaya 2011). A similar theory uses the true form quotient defined by diameters measured above the ground at 0.1 of tree height $(H)$ and $0.3 \times H$ (Giurgiu et al. 2004). If the median diameter value of the stem profile is known, the stem volume may be computed using the Mathiesen's formula (Mathiesen 1925 - eqn. 1):

$$
v=\frac{3}{4} \cdot D M \cdot A
$$

where $D M$ is the median diameter of the stem profile; and $A$ is the total area of the stem profile $\left(\sum A_{i}\right)$. The area of each section, $A_{i}\left(L \times D_{i}\right)$ is based on $L$, the length of the stem sections, while $D_{i}$ represents the diameter at the middle of the sections $i$ ( $i$ $=1,2, \ldots, n)$. This method was proposed in 1925 , with its principle considering the center of gravity of the median diameter in relation to the area of the stem profile. The median diameter is defined as the diameter that divides the stem profile into two equal parts of the area. However, because laborious calculation is required, Mathiesen's formula is avoided in practice, with Huber's formula being preferred to determine the precise volume of the tree stem (Ichim 1954, Leahu 2007). The size of median diameter may be found from the area when the profile shape is known, using graphical softwares such as those used in geodesy (Teresneu \& Ionescu 2011, Teresneu 2012). However, in practice, it is diffi- 


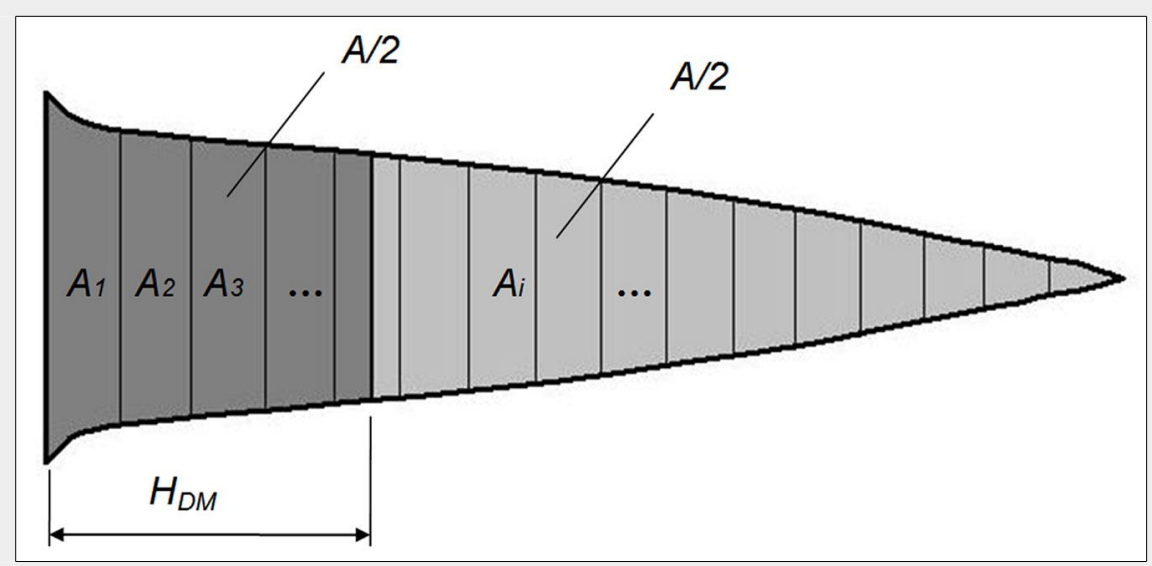

Fig. 1 - Position of the median diameter $(D M)$ on the stem profile. $\left(H_{D M}\right)$ : height of the median diameter along the stem; $(A)$ : area of the stem profile; $\left(A_{i}\right)$ : area of the $i$-th longitudinal section. $D M$ divides the stem profile into two parts of equal area $(A / 2)$.

cult to measure the shape of the profile, making this method inefficient.

This study aimed to develop a more rapid method for assessing the median diameter of the stem profile of Norway spruce trees (Picea abies Karst.). Such a method allows the Mathiesen's formula to become a feasible tool for practical use. In addition, because tree resistance is related to stem mass (Peltola 2006, Urata et al. 2011), the median diameter computed for the area of the stem profile could be used to study tree resistance against the wind. Given the importance and forested area covered by Norway spruce in Romania (22\% - Sofletea \& Curtu 2007), the study focused on this tree species.

\section{Materials and methods}

\section{Materials}

A database was established in 2012 by compiling the stem diameters of 5403 Norway spruce trees from Romania, grouped into 218 diameter-height classes (Tab. S1 in Supplementary material). Original mea-

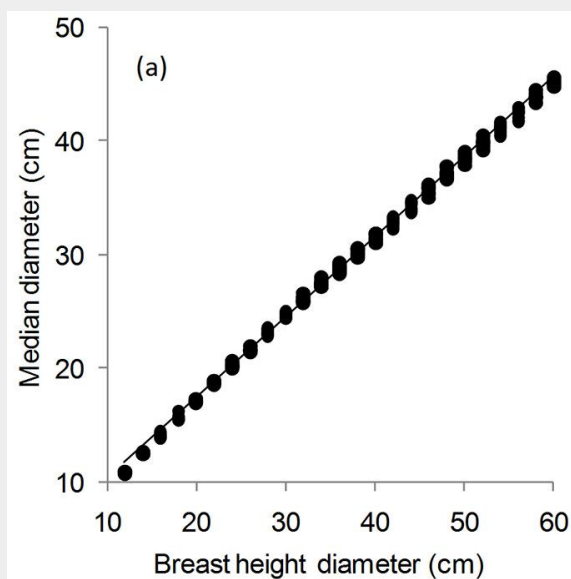

where $A_{D_{1} 1}$ and $A_{D_{2} 2}$ are the areas with values under and above $A / 2$ in the row of the cumulated areas of the sections; $D M_{1}$ and $\mathrm{DM}_{2}$ are the corresponding values for diameters of $A_{D M_{1}}$ and $A_{D M_{2}}$, respectively. The parameter $H_{D M}$ can be estimated using eqn. 3:

$$
H_{D M}=H_{D M 1}+\left(H_{D M 2}-H_{D M 1}\right) \cdot \frac{D M_{1}-D M}{D M_{1}-D M_{2}}
$$

where $H_{D_{1} 1}$ and $H_{D_{2} 2}$ are the distances between the lower end of the trunk and the point where $D M_{1}$ and $D M_{2}$ occur. Consequently, $H_{\text {DMrel }}$ may be derived as follows (eqn. 4):

$$
H_{D M r e l}=\frac{H_{D M}}{H}
$$

\section{Data analysis}

From the previous work (Vasilescu 2013), data for breast height diameters were grouped into 25 diameter classes of size 2 $\mathrm{cm}$. Total heights were also assigned to classes of $2 \mathrm{~m}$ in size.

A correlation analysis was applied to test the association between the median diameter at breast height (DBH) and $D M, H_{D M}$, and $H_{D M r e l}$. Similarly, the association of tree height $(H)$ with $D M, H_{D M}$, and $H_{D M r e l}$ was also tested. Moreover, $\mathrm{DBH}$ and $\mathrm{H}$ were used as independent variables in regression analysis to establish a rapid method for estimating the median diameter. The best fitted models to express the relationship between median diameter or its height and tree size data were examined using the $F$ (Fisher) test. The accuracy of the models for the median diameter of the stem profile was estimated by computing the bias as (eqn. 5):

$$
\operatorname{Bias}_{D M}=\frac{D M_{e s t}-D M_{o b s}}{D M_{o b s}} \cdot 100
$$

The coefficient of variation within each breast height diameter class was computed for height, median diameter of the stem profile, and absolute and relative height of the median diameter, in order to assess data homogeneity.

\section{Results and discussion}

\section{Relationship between median diameter} and tree size

The evolution of the median diameter of the stem profile as a function of breast height diameter for Norway spruce trees in Romania is shown in Fig. 2a. A significant, positive relationship was found by regression analysis $\left(R^{2}=0.9985 ; F=143871.1 ; d f=\right.$ $1,216 ; P<0.0001)$, and the following regression model was obtained (eqn. 6):

\section{$D M=0.7061 \cdot D B H+3.235$}

The same values of median diameter grouped by total tree height indicated a large variation for each tree height class (Fig. 2b). Using pairs, defined by median diameter and tree height, the coefficient of
Fig. 2 - Regression analysis of the median diameter of the stem profile in Picea abies Karst. With: (a) breast height diameter; and (b) height. Best fitting models are shown by solid lines ( $F$ test: $n=218, P<0.001)$. 
determination $\left(R^{2}\right)$ was only 0.5523 . The best fitted model in this case was a polynomial expression (eqn. 7):

$$
D M=-0.0111 \cdot H^{2}+1.5076 \cdot H-3.4374
$$

$\left(R^{2}=0.5523 ; F=132.6324 ; d f=2,215 ; P<\right.$ $0.0001)$. However, the model accuracy was lower than that obtained using eqn. 6 .

\section{Analysis of the absolute height of median diameter}

The relationships of the absolute height of the median diameter with the diameter at breast height (DBH) and the total height $(\mathrm{H})$ are shown in Fig. $3 \mathrm{a}$ and Fig. 3b, respectively. The polynomial regression applied indicated a weaker relationship in the first case $\left(R^{2}=0.4573 ; F=90.5741 ; d f=2,215 ; P<\right.$ $0.0001)$ as compared with the second case $\left(R^{2}=0.9876 ; F=17234.41 ; d f=1,216 ; P<\right.$ $0.0001)$. The best fitted models using $D B H$ and $H$ as predictors were as follows (eqn. 8 and eqn. 9, respectively):

$$
\begin{gathered}
H_{D M}=-0.0030 \cdot D B H^{2}+0.3421 \cdot D B H+0.3698 \\
H_{D M}=0.3288 \cdot H-0.7621
\end{gathered}
$$

The low accuracy of the first model (eqn. 8) was confirmed by the large dispersion of values of $H_{\mathrm{DM}}$, as depicted in Fig. $3 \mathrm{a}$.

A positive correlation was detected between the absolute height of the median diameter and tree height $(r=0.9937)$.

\section{Analysis of the relative height of} median diameter

The core of this study is the analysis of the relationship of the relative height of median diameter $\left(H_{\text {DMrel }}\right)$ with $D B H$ and $H$ in Norway spruce trees. Our results showed that the relative height along the stem profile where the median diameter is recorded was poorly correlated with the breast height diameter (Fig. 4a). $H_{\text {DMrel }}$ values were mainly distributed along and around a horizontal asymptote (intercept $=0.2961, t_{[216]}=$ 103.0696, $P<0.0001)$, according to the following relationship (eqn. 10):

$$
H_{\text {DMrel }} \approx 0.3
$$

The mean $H_{\text {DMrel }}$ value computed using all the 218 tree size classes was $0.298695 \pm$ 0.001936 ( $95 \%$ confidence interval), with a low coefficient of variation ( $4.88 \%)$, indicating fairly homogenous samples.

The results revealed that the median diameter of the longitudinal sections of the stem could be determined as approximately $0.3 \times \mathrm{H}$ in the case of Norway spruce trees in Romania.

The relationship between the relative height of the median diameter along the stem and total tree height (Fig. 4b) was modeled using a polynomial regression, obtaining the following best-fitting model $\left(R^{2}=0.5344 ; F=123.4187 ; d f=2,215 ; P<\right.$ 0.0001 - eqn. 11$)$ :

$H_{\text {DMrel }}=0.22738+0.004132 \cdot H-0.000052 \cdot H^{2}$
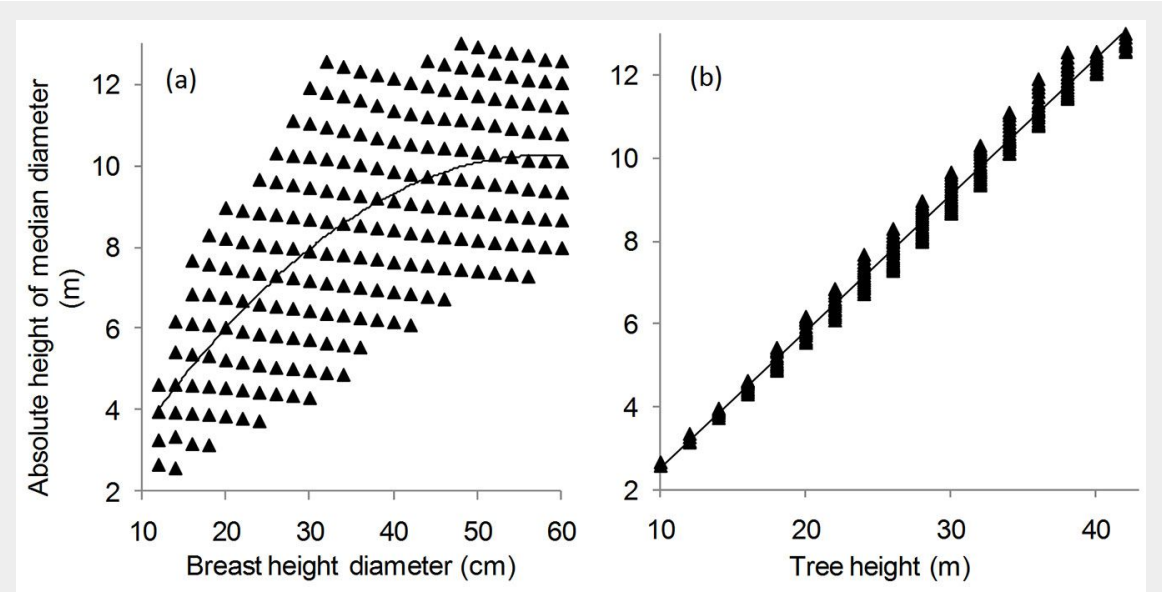

Fig. 3 - Relationship of the absolute height of the median diameter along the stem profile with: (a) breast height diameter; and (b) tree height. Best fitting models are shown by solid lines ( $F$ test: $n=218 ; P<0.001$ ).

\section{Data variability}

The coefficient of variation was computed for each breast height diameter class of each studied variable of the stem profile: tree height, median diameter of the longitudinal section, and absolute and relative height of median diameter.

The classes of diameter at breast height were homogenous for all the studied variables. The coefficient of variation was lower than $30 \%$ in most cases, ranging between $13.99 \%$ and $25.78 \%$ for total height, and between $15.73 \%$ and $31.64 \%$ for the absolute height of the median diameter on the stem. For comparison, the median diameter values (range: $0.60 \%$ to $1.64 \%$ ) and the relative location of median diameter values (range: $2.04 \%$ to $6.74 \%$ ) were significantly lower. Due to high data homogeneity, arithmetic means of the $\mathrm{DBH}$ classes were used. In this case, the arithmetic mean of all $H_{\text {DMrel }}$ mean values was 0.2978 . The observed variation of values in all 25 breast height diameter classes was

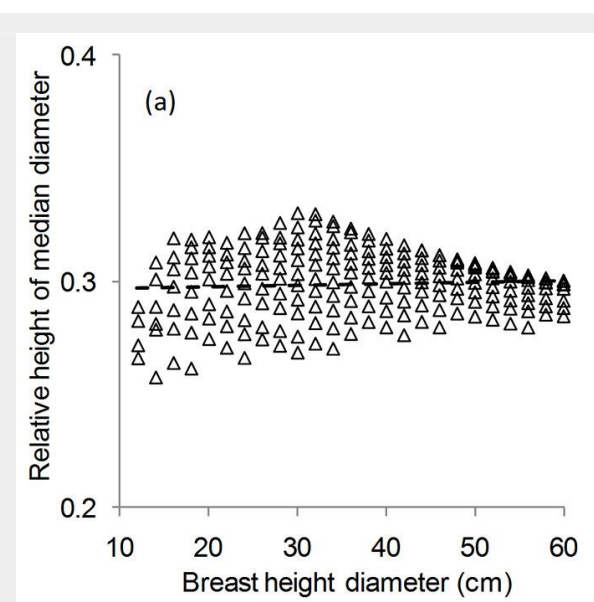

extremely low (coefficient of variation = $1.99 \%)$.

\section{Accuracy of predictive models}

The median diameter of the stem profile assessed using DBH (eqn. 6) was compared with the "true" median diameter using classical methods (eqn. 2), obtaining a maximum absolute difference of $0.88 \mathrm{~cm}$. For $57.34 \%$ of the analyzed trees, even a lower difference was observed (between -3 and $3 \mathrm{~mm}$ ).

We also calculated the relative deviation of median diameter estimates obtained with the two aforementioned methods using both $\mathrm{DBH}$ and $\mathrm{H}$ as predictors (Fig. 5a, Fig. 5b). Results showed that such deviation was lower than $2 \%$ in $86.24 \%$ of the analyzed trees. The observed relative differences amounted to $7.60 \%$ for smaller trees in the range $12-14 \mathrm{~cm}$ for $\mathrm{DBH}$, or 10-14 $\mathrm{m}$ for $\mathrm{H}$. Similar differences were obtained when comparing diameters measured at $0.3 \times \mathrm{H}$ to the median diameter of the stem

\section{4}

(b)

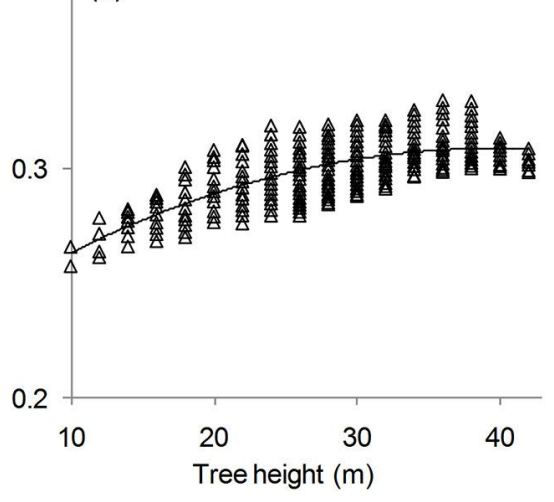

Fig. 4 - Values of the relative height of median diameter along the stem with respect to: (a) the class of breast height diameter; and (b) the tree height class. The best fitting model is shown by a solid line ( $F$ test: $n=218$; $P<0.001)$, while the dashed line represents the horizontal asymptote, $H_{\text {DMrel }}=0.2961$ ( $F$ test: $n=218 ; P<0.001$ ). 


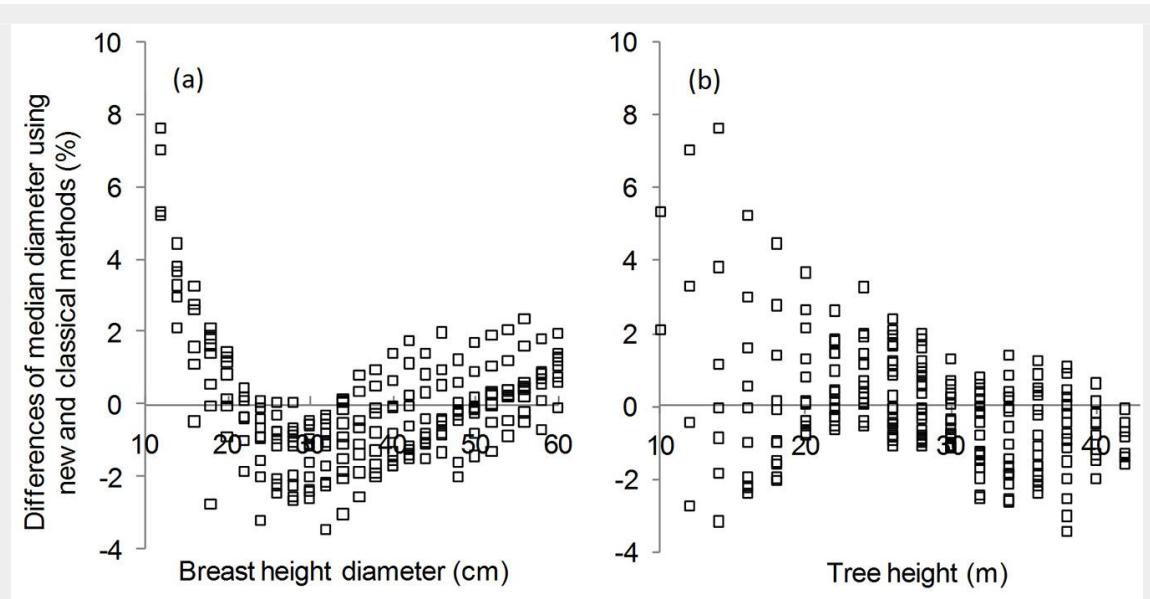

Fig. 5 - Relative difference (\%) of median diameter estimates with: (a) the class of breast height diameter; (b) the tree height class. The depicted model for predicting median diameter values is: $\mathrm{DM}=0.7061 \mathrm{DBH}+3.235$.

Tab. 1 - Predictive models of median diameter and its absolute and relative height along the stem obtained by multiple regression analysis.

\begin{tabular}{lccrc}
\hline Best fitted models & $\boldsymbol{R}^{2}$ & df & \multicolumn{1}{c}{$\boldsymbol{F}$} & \multicolumn{1}{c}{$\mathbf{P}$} \\
\hline$D M=2.716099+0.688689 D B H+0.041612 H$ & 0.999055 & 2,215 & 113689.80 & $<0.0001$ \\
$H_{\text {DM }}=-0.703391-0.029121 D B H+0.365176 H$ & 0.998636 & 2,215 & 78681.77 & $<0.0001$ \\
$H_{\text {DMrel }}=0.264829-0.000983 D B H+0.002511 H$ & 0.873587 & 2,215 & 742.88 & $<0.0001$ \\
\hline
\end{tabular}

profile using the classical method.

Tab. 1 displays the best fitted models for the median diameter of the stem profile, and absolute and relative height of the median diameter position. As expected, $D M, H_{D M}$, and $H_{D M r e l}$ were best predicted by using both independent variables (DBH and H) as predictors.

\section{Model selection for practice}

Our results indicated that two aforementioned methods could be used to obtain a rapid assessment of median diameter of the stem profile for Norway spruce trees in Romania, specifically: (i) using eqn. 6 based on tree $\mathrm{DBH}$, or its simplified form to be applied when less accuracy is required

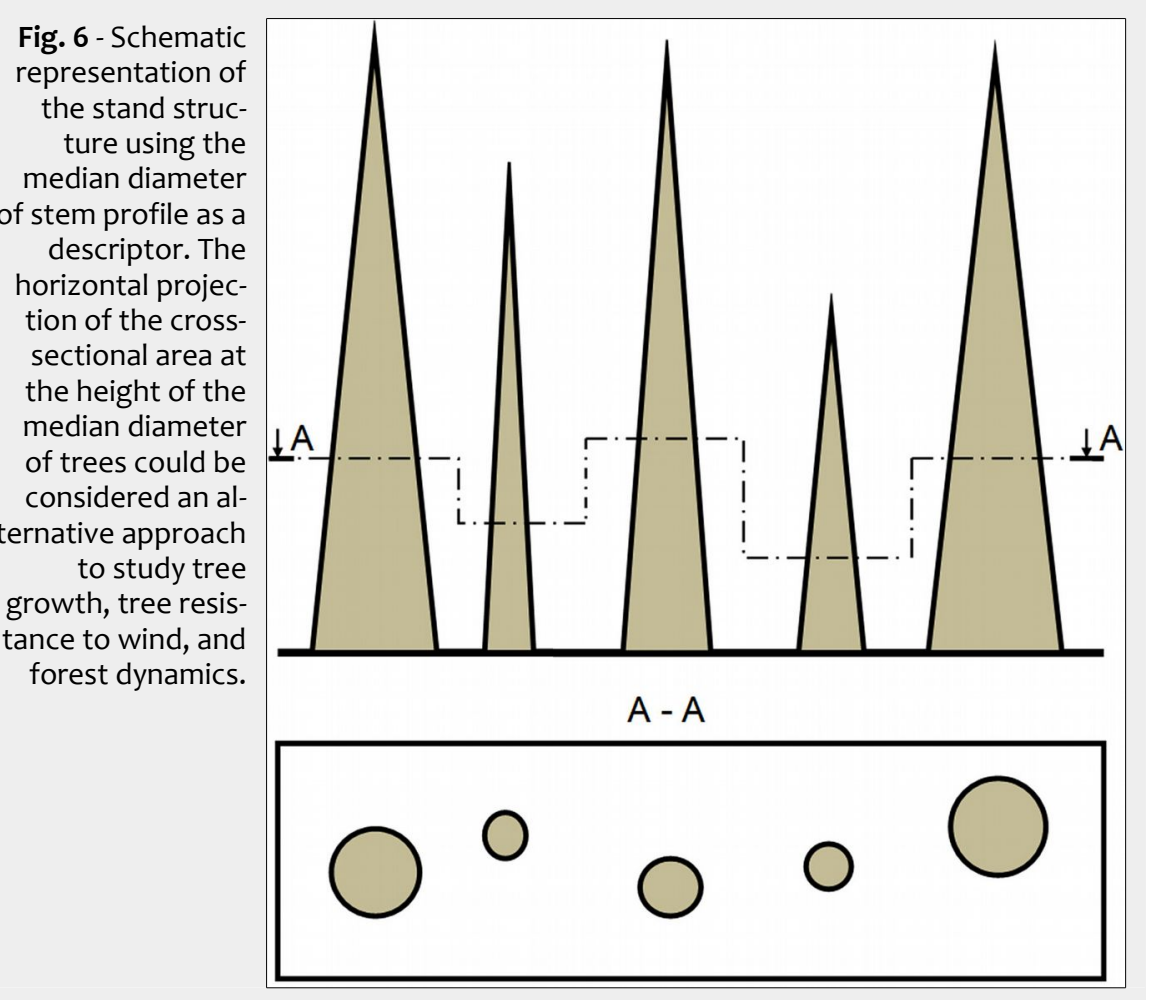

(eqn. 12):

$$
D M=0.7 \cdot D B H+3
$$

(ii) measuring the stem diameter at $0.3 \times \mathrm{H}$ distance from the base of the trunk.

The first method only involves measuring breast height diameter and a simple calculation for both standing and felled trees. The second method requires the measurement of tree length (considered to be equal to tree height), followed by the direct measurement of the median diameter at $0.3 \times \mathrm{H}$ distance from the stem base. These results support the empirical evidence of Forslund (1982), whereby the average center of gravity of aspen boles without branches is located at 3/10 of the bole height from its base. Wood et al. (1990) also showed the importance of the point on the stem at a relative height of approximately 0.3 . They obtained a minimum bias in the estimation of tree volume, using centroid sampling for 114 trees of radiata pine, where the point of sampling was fixed at the height of the centroid.

\section{Perspectives of easier computation of} the median diameter

The practical implications of the proposed methods are relevant, particularly when the relative height of the median diameter is correlated with the distribution of volume in trees. These methods should be applied to other species to validate their use, especially in the case of conifers. The Mathiesen's formula for volume estimation could be modified and improved by using the proposed models. Our results demonstrated the feasibility of assessing the stand volume using the median diameter of the stem profile. For two species of pines (loblolly and ponderosa pine), Coble \& Wiant (2000) illustrated the accuracy of the centroid method for determining volumes of standing trees, requiring only the diameter measurement of one upper stem.

The median diameter of the stem profile could be used to study stand architecture and competition between trees (Fig. 6). Indeed, median diameter distributions from forest inventories provide a more precise way of describing forest stand structure and the relationships between trees. Moreover, DM may allow the development of forest growth models (similar to those used in Switzerland) to estimate the growth of single trees based on $\mathrm{DBH}, \mathrm{H}$, and a given upper stem diameter (Van Laar \& Akça 2007). Furthermore, the possibility of using the $0.3 \times \mathrm{H}$ estimated in this study as an index of tree competition could be explored. Biging \& Dobbertin (1995) proposed several crown competition indexes based on evaluation at one-third, one-half, two-thirds and other relative heights of study trees.

Compared to $\mathrm{DBH}, \mathrm{DM}$ provides a more accurate prediction of the stem form. It also provides a better way of indicating the response of tree form to variability in envi- 
ronmental factors. For instance, Pollanschütz (1965) used a three-variate ( $D B H, H$, and diameter at $0.3 \times \mathrm{H}$ ) model to calculate the form factor. This point along the stem better characterizes the ability of a tree to respond to ecological factors. Fifty percent of the area of the stem profile and approximately $50 \%$ of the stem volume are concentrated below the cross-sectional area at the height of median diameter $(0.3 \times \mathrm{H}$, according to our study). Moreover, the horizontal projection of the cross-sectional area corresponding to DM might represent a new approach to assess tree stability and failure. Furthermore, the core of juvenile wood below the crown is more or less constant, whereas that of adult wood covering this core decreases from the base to the tip (Brüchert et al. 2000). Therefore, the cross section of the stem located near the median diameter exhibits a particular mechanical behavior. Indeed, Young's modulus seems to be at its lowest in the bottom part of Norway spruce trees (Brüchert et al. 2000).

Resistance of a tree depend on many factors. Gardiner et al. (2008) observed that stem characteristics (diameter and wood strength), root plate morphology, soil type, and soil moisture vary widely depending on the location of the tree crown within the canopy, tree species, stand location, and wind exposure. A tree is assumed to break when the stress acting on the stem exceeds a critical value of the modulus of rupture (Peltola et al. 1999). Based on this assumption, Peltola et al. (1999) developed a model to assess the risk of wind and snow damage to single trees and stands of Norway spruce. For individual Scots pine and Norway spruce, Gardiner et al. (2000) compared two models developed to predict the critical wind speed required to damage coniferous trees with varying tree height and stem taper $(\mathrm{DBH} / \mathrm{H})$. The ratio defined by the median diameter of the stem profile and tree height $(D M / H)$ helps to determine the breaking strength of the stem and, hence, tree resistance to overturning. Ancelin et al. (2004) also developed a model of tree response to wind, based on the numerical description of tree structure. This concept is compatible with a model of coniferous forest stand dynamics. Thus, we recommend using the median diameter of the stem profile to predict the sensitivity of trees breakage and bending.

\section{Conclusions}

Our study developed two methods to assess the median diameter of the stem profile without measuring multiple diameters at different heights along the stem. The median diameter may be obtained without classical computations that require the area of the stem profile. We demonstrated that diameter at $0.3 \times$ height is a good approximation of the median diameter. Accuracy analysis of the proposed models indicates differences $<2 \%$ in most cases. Tree distribution based on the median diameter of the stem profile represents a new direction for forest dynamics studies. The ratio between the median diameter of stem profile and the tree height $(D M / H)$ could be applied for measuring other economically important factors, including the breaking strength of the stem and tree resistance to overturning.

\section{Acknowledgements}

We thank Andres Kiviste and Allan Sims (Institute of Forestry and Rural Engineering, Estonian University of Life Science) for providing Mathiesen's original paper (1925). We thank Paolo Cherubini (WSL Swiss Federal Institute for Forest, Snow and Landscape Research), Tudor Stancioiu, and Alexandru Borz (Faculty of Silviculture and Forest Engineering, Transilvania University of Brasov) for providing valuable comments on the manuscript.

\section{Author contributions}

MMV originally formulated the concept and elaborated the database; MMV and CCT developed the methodology; MMV, FD, and CCT analysed the data; MMV formulated the mathematical models; and $M M V$ and FD wrote the manuscript.

\section{References}

Akossou A, Arzouma S, Attakpa E, Fonton N, Kokou K (2013). Scaling of teak (Tectona grandis) logs by the xylometer technique: accuracy of volume equations and influence of the log length. Diversity 5: 99-113. - doi: 10.3390/d5010 099

Ancelin P, Courbaud B, Fourcaud T (2004). Development of an individual tree-based mechanical model to predict wind damage within forest stands. Forest Ecology and Management 203: 101-121. - doi: 10.1016/j.foreco.2004.07.067

Avery TE, Burkhart H (1983). Forest measurements. McGraw-Hill, New York, USA, pp. 331. [online] URL: http://www.cabdirect.org/cabdi rect/abstract/19830684098

Biging GS, Dobbertin M (1995). Evaluation of competition indices in individual tree growth models. Forest Science 41: 360-377. [online] URL: http://www.ingentaconnect.com/content/ saf/fs/1995/00000041/00000002/art00013

Brüchert F, Becker G, Speck T (2000). The mechanics of Norway spruce [Picea abies (L.) Karst]: mechanical properties of standing trees from different thinning regimes. Forest Ecology and Management 135: 45-62. - doi: 10.1016/S03781127(00)00297-8

Coble DW, Wiant HV (2000). Centroid method: comparison of simple and complex proxy tree taper functions. Forest Science 46: 473-477. [online] URL: http://www.ingentaconnect.com/ content/saf/fs/2000/00000046/00000004/arto 0001

Coble DW, Lee YJ (2003). Use of the centroid method to estimate volumes of Japanese red cedar trees in southern Korea. Korean Journal of Ecology 26: 123-127. - doi: 10.5141/JEFB.2003. 26.3.123

Ducey M, Williams M (2011). Comparison of Hossfeld's method and two modern methods for volume estimation of standing trees. Western Journal of Applied Forestry 26: 19-23. [online] URL: http://www.ingentaconnect.com/content/ saf/wjaf/2011/00000026/00000001/art00003

Durkaya B, Durkaya A (2011). Tomruk hacminin hesaplanmasinda kullanilan ciesitli hacim formüllerinin karsilasitirilmasi [Comparing different formulas using log volume estimations]. Bartin Orman Fakültesi Dergisi 13: 18-22. [in Turkish]

Forslund R (1982). A geometrical tree volume model based on the location of the centre of gravity of the bole. Canadian Journal of Forest Research 12: 215-221. - doi: 10.1139/×82-033

Gardiner B, Peltola H, Kellomäki S (2000). Comparison of two models for predicting the critical wind speeds required to damage coniferous trees. Ecological Modelling 129: 1-23. - doi: 10.1016/S0304-3800(00)00220-9

Gardiner B, Byrne K, Hale S, Kamimura K, Mitchell S, Peltola H, Ruel JC (2008). A review of mechanistic modelling of wind damage risk to forests. Forestry 81: 447-463. - doi: 10.1093/ forestry/cpno22

Giurgiu V (1979). Dendrometrie si auxologie forestiera [Forest biometry]. Ed. Ceres, Bucharest, Romania, pp. 692. [in Romanian]

Giurgiu V, Decei I, Draghiciu D (2004). Metode si tabele dendrometrice [Methods and tables of forest mensuration]. Ed. Ceres, Bucharest, Romania, pp. 575. [in Romanian]

Hamilton GJ (1988). Forest mensuration handbook. Forestry Commission Booklet 39, HMSO, London, UK, pp. 275.

Husch B, Beers TH, Kershaw J (2003). Forest mensuration. John Wiley and Sons, New Jersey, USA, pp. 433.

Ichim R (1954). Cubajul bustenilor si al arborilor fara varf prin metoda centrului de greutate (Procedeul Guldin - Mathiesen II) [Bole volume and tree volume using centre of gravity method - second method by Guldin - Mathiesen]. Revista Padurilor 11: 25-31. [in Romanian]

Leahu I (1994). Dendrometrie [Forest mensuration]. EDP, Bucharest, Romania, pp. 374. [in Romanian]

Leahu I (2007). Dendrometrie [Forest mensuration]. Transilvania University Press, Brasov, Romania, pp. 130. [in Romanian]

Mathiesen A (1925). Tüve pikuti läbilõike pind faktor tüve massi määramiseks [The area of the stem's longitudinal section - predictor of the volume estimation]. Ed. Bergmann, Tartu, EE, pp. 31. [in Estonian]

Ozcelik R, Wiant Jr H, Brooks J (2006). Estimating log volumes of three tree species in Turkey by six formulae. Forest Product Journal 56: 8486. [online] URL: http://search.proquest.com/o penview/8569fffaff7a27a08293a2e72e17b184/1 Parent D, Moore J (2003). A stand volume equation for cruising small-diameter material. Journal of Forestry 101: 5-6. [online] URL: http:// www.ingentaconnect.com/content/saf/jof/200 3/00000101/00000005/art00004

Peltola H (2006). Mechanical stability of trees under static loads. American Journal of Botany 93: 1501-1511. - doi: 10.3732/ajb.93.10.1501

Peltola H, Kellomäki S, Väisänen H, Ikonen VP (1999). A mechanistic model for assessing the risk of wind and snow damage to single trees and stands of Scots pine, Norway spruce, and 
birch. Canadian Journal of Forest Research 29: 647-661. - doi: 10.1139/x99-029

Philip M (1994). Measuring trees and forests. Cab International, London, UK, pp. 320. [online] URL: http://www.cabdirect.org/cabdi rect/abstract/19940600622

Pollanschütz J (1965). Eine neue methode der formzahl und massenbestimmung stehender stämme [A new method of determining form factor and volume of standing trees]. Österreichischer Agrarverlag, Vienna, Austria, pp. 186. [in German]

Popescu-Zeletin I, Toma G, Armasescu S, Decei I, Dissescu R, Petrescu L, Dorin T, Stanescu M, Predescu GH (1957). Tabele dendrometrice [Tables of forest mensuration]. Ed. Agro-silvica de Stat, Bucharest, Romania, pp. 1319. [in Romanian]

Schiffel A (1899). Form and inhalt der Fichte [Form and volume of spruce trees]. Wien Frick, Vienna, AT, pp. 139. [in German]

Soares CPB, Da Silva GF, Martins FB (2010). Influence on section lengths on volume determination in Eucalyptus tree. Cerne 16: 155-162. - doi: 10.1590/S0104-77602010000200006

Sofletea N, Curtu L (2007). Dendrologie [Dendrology]. Transilvania University Press, Brasov, Romania, pp. 540. [in Romanian]

Teresneu C, Ionescu M (2011). Infografica pentru topografie si cadastru [Informatics for topogra- phy and cadastre]. Ed. Lux Libris, Brasov, Romania, pp. 404. [in Romanian]

Teresneu C (2012). Prelucrarea automata a datelor geodezice [Automation of geodetic data]. Transilvania University Press, Brasov, Romania, pp. 251. [in Romanian]

Tomusiak R, Zarzynski P (2007). The old trees trunk's volume determination with use of theodolite. Rocznik Dendrologiczny 55: 9-16.

Urata T, Shibuya M, Koizumi A, Torita H, Cha JY (2011). Both stem and crown mass affect tree resistance to uprooting. Journal of Forest Research 17: 65-71. - doi: 10.1007/s10310-011-0249-6 Van Laar A, Akça A (1997). Forest mensuration. Cuvillier Verlag, Göttingen, Gemany, pp. 418.

Van Laar A, Akça A (2007). Forest mensuration. Springer, Dordrecht, Netherlands, pp. 383. [online] URL: http://books.google.com/books? id=ybjdxL2IHOQC

Vasilescu MM (2013). The relative level of median diameter on the longitudinal section of Norway spruce (Picea abies (L.) Karst) stem. In: "Forest and Sustainable Development". Transilvania University Press, Brasov, Romania, pp. 129-132. [online] URL: http://www.cabdirect. org/cabdirect/abstract/20133203661

West PW (2009). Tree and forest measurement. Springer-Verlag, Berlin, Germany, pp. 191. - doi: 10.1007/978-3-319-14708-6

Wiant H, Wood G, Forslund R (1991). Comparison of centroid and paracone estimates of tree volume. Canadian Journal of Forest Research 21: 714-717. - doi: 10.1139/x91-099

Wiant H, Spangler M, Baumgras J (2002). Comparison of estimates of hardwood bole volume using importance sampling, the centroid method, and some taper equations. Northern Journal of Applied Forestry 19: 141-142. [online] URL: http://www.nrs.fs.fed.us/pubs/jrnl/2002/ne_200 2_wiant_001.pdf

Wood G, Wiant Jr H, Loy R, Miles J (1990). Centroid sampling: a variant of importance sampling for estimating the volume of sample trees of radiata pine. Forest Ecology and Management 36: 233-243. - doi: 10.1016/0378-1127(90) 90027-9

Yavuz H (1999). Comparison of the centroid method and four standard formulas for estimating log volumes. Turkish Journal of Agriculture and Forestry 23: 597-602. [online] URL: http://journals.tubitak.gov.tr/agriculture/abstra ct.htm?id=3607

\section{Supplementary Material}

Tab. S1 - Classical computation of the median diameter.

Link:Vasilescu_1945@supploo1.pdf 